\title{
IDENTIFIKASI KESULITAN SISWA SD DALAM MEMAHAMI KEMAMPUAN VERBAL DAN NUMERIK BERBASIS MASALAH MATEMATIKA TAHUN PELAJARAN 2018/2019
}

\author{
Yuni Mariyati' ${ }^{1}$ Sintayana Muhardini ${ }^{2}$, Sukron Fujiaturrahman ${ }^{3}$ \\ Program Studi Guru Sekolah Dasar (PGSD) Universitas Muhammadiyah Mataram \\ yunimariyati31@gmail.com
}

\begin{tabular}{l} 
INFO ARTIKEL \\
\hline Riwayat Artikel: \\
Diterima:10 -12-2018 \\
Disetujui:18-01-2019 \\
\hline Kata Kunci: \\
Kesulitan peserta didik \\
Masalah matematika \\
Kemampuan verbal \\
Kemampuan numerik
\end{tabular}

\section{Keywords:}

Student difficulties

Mathematical problems

Verbal abilities

Numerical abilities

\begin{abstract}
ABSTRAK
Abstrak: Penelitian ini bertujuan untuk mengetahui faktor-faktor yang mempengaruhi kesulitan siswa dilihat dari kemampuan verbal dan numerik siswa dalam memecahkan masalah matematika pada materi KPK. Penelitian ini menggunakan pendekatan kualitatif yang bersifat deskriptif dengan menggambarkan proses penelitian secara benar sesuai dengan fakta yang di dapatkan. Dalam penelitian ini subjek penelitian sebanyak 30 peserta. Siswa yang terpilih sebagai subjek penelitian tersebut adalah siswa kelas IV. Data dikumpulkan dengan pemberian tes soal dan wawancara. Tes soal yang digunakan berbentuk soal cerita. Hasil penelitian menunjukkan bahwa faktor-faktor yang mempengaruhi kesulitan peserta didik dalam kemampuan verbal adalah peserta didik kurang mampu memahami permasalahan atau soal yang diberikan, selain itu siswa sulit dalam membahasakan hasil perhitungannya sebagai jawaban akhir atas permasalahan matematika yang diberikan, sedangkan faktor-faktor yang mempengaruhi kesulitan peserta didik dalam kemampuan numerik adalah peserta didik tidak memahami rumus yaitu salah dalam menentukan kelipatan dan salah dalam menentukan KPK dengan menggunakan pohon factor
\end{abstract}

\begin{abstract}
This study aims to determine the factors that influence student difficulties seen from the verbal and numerical abilities of students in solving mathematical problems in the KPK material. This study uses a qualitative approach that is descriptive by describing the research process correctly in accordance with the facts obtained. In this study, the subject of the study were 30 students grade IV students. Data was collected by giving question tests and interviews. The test questions used are in the form of story problems. The results showed that the factors that influence the difficulties of students in verbal abilities were students were less able to understand the problems or questions given, other than that the students find it difficult to express the results of their calculations as the final answer to the mathematical problems given, while the factors that influence the difficulty of students in numerical abilities are students who do not understand the formula which is wrong in determining multiples and wrong in determining the KPK by using a tree factor.
\end{abstract}

\section{A. LATAR BELAKANG}

Pendidikan merupakan salah satu unsur penting yang mempengaruhi kelangsungan hidup manusia, baik secara langsung maupun tidak langsung. Telah tersirat dalam tujuan pendidikan nasional berdasarkan UU 20 tahun 2003 pasal 3 yaitu: pendidikan nasional berfungsi mengembangkan kemampuan dan membentuk watak serta peradaban bangsa yang bermanfaat dalam rangka mencerdaskan kehidupan bangsa, bertujuan untuk berkembangnya peserta didik agar menjadi manusia yang beriman dan bertakwa kepada Tuhan Yang Maha Esa, berahlak mulia, sehat, berilmu, cakap, kreatif, mandiri, dan menjadi warga negara yang demokrasi serta bertanggung jawab.

Matematika adalah salah satu mata pelajaran wajib di sekolah dalam tingkatan apapun yang memiliki tujuan yang tersirat secara langsung pada tujuan pendidikan nasional. Tujuan pembelajaran matematika di Indonesia termuat dalam Permendiknas Nomor 22 Tahun 2006. Mata pelajaran matematika bertujuan agar peserta didik memiliki kemampuan sebagai berikut: (1) Memahami konsep matematika, menjelaskan keterkaitan antar konsep dan mangaplikasikan konsep atau algoritma, secara luas, akurat, efisien, dan tepat, dalam pemecahan masalah. (2) Menggunakan penalaran 
pada pola dan sifat melakukan manipulasi matematika dalam membuat generalisasi, menyusun bukti, atau menjelaskan gagasan dan pernyataan matematika. (3) Memecahkan masalah yang meliputi kemampuan memahami masalah, merancang model matematika, menyelesaikan model dan menafsirkan solusi yang di peroleh. (4) Mengkomunikasikan gagasan dengan simbol, tabel, diagram atau media lain untuk memperjelas keadaan atau masalah.

Dalam kegiatan proses belajar mengajar matematika terdapat komunikasi antara guru dan siswa atau siswa dengan siswa. Dalam berkomunikasi guru harus bisa memberikan penjelasan tentang materi pelajaran yaitu dengan menggunakan bahasa yang dapat dimengerti oleh siswa. Jika bahasa yang digunakan dalam menjelaskan materi tidak dipahami oleh siswa, maka akan menimbulkan kesulitan bagi siswa dalam menguasai materi pelajaran tersebut. Kemampuan verbal yang memadai sangat di perlukan dalam menyelesaikan soal-soal matematika dalam bentuk cerita, karena dalam kemampuan verbal maka siswa akan lebih mudah dalam mengartikan maksud soal. Senada dengan pernyataan Sukardi (2015:115) mengemukakan bahwa kemampuan verbal adalah kemampuan memahami ide-ide yang di ekspresikan dalam bentuk kata-kata. Jadi kemampuan verbal yang dimaksud dalam penelitian ini adalah kemampuan mengartikan kata-kata atau kalimat dalam soal. Selain itu, untuk menguasai materi soal cerita siswa harus memiliki kemampuan dalam mengoperasikan bilangan secara manual dengan operasi hitung biasa seperti operasi perkalian dan pembagian, sehingga kemampuan numerik juga diperlukan dalam menyelesaikan soal-soal matematika

Berdasarkan informasi dari guru kelas IV di SDN 2 Tamansari Gunungsari, diketahui bahwa pemecahan masalah matematika khusus soal cerita pada materi KPK merupakan materi yang dianggap sulit oleh siswa. Hal ini terlihat dari nilai rata-rata ulangan harian siswa pada penyelesaian masalah matematika pada materi KPK sangat rendah. Hal ini dapat di lihat dari nilai rata-rata ulangan pada pokok bahasan KPK bernilai 48,9. Selain itu, bahwa sebagian besar siswa masih kurang mampu menterjemahkan soal-soal yang berbentuk cerita ke dalam simbol matematika. Jadi diduga bahwa kemampuan verbal siswa masih kurang memadai. Seorang siswa yang kemampuan verbalnya kurang akan mengalami kesulitan dalam memahami dan menterjemahkan maksud soal ke dalam simbol matematika dan akhirnya siswa tidak mampu menyelesaikan soal tersebut. Akibatnya penguasaan matematika siswa ( hasil belajarnya ) akan menjadi rendah. Nilai ulangan materi KPK dari 34 peserta didik terdapat 28 peserta didik yang belum memenuhi KBM (Kriteria Belajar Minimum) yaitu sebesar 65 (Dokumentasi, SDN 2 Tamansari).
Berdasarkan latar belakang tersebut, penulis berusaha untuk menggali faktor-faktor apa saja yang menyebabkan peserta didik di SDN 2 Tamansari ini mengalami kesulitan dalam memecahkan masalah matematika pada materi KPK, sehingga diharapkan guru dapat mengambil atau menentukan usaha yang tepat untuk mengatasi masalah tersebut demi perbaikan dalam pembelajaran matematika.

Berdasarkan latar belakang tersebut dapat ditarik rumusan masalah, apakah faktor-faktor yang mempengaruhi kesulitan siswa dalam memahami kemampuan verbal dan numerik terhadap soal cerita berbasis masalah pada materi KPK ?

Tujuan penelitian yang hendak dicapai dalam penelitian ini yaitu untuk mengetahui faktor-faktor yang mempengaruhi kesulitan siswa dalam memahami kemampuan verbal dan numerik terhadap terhadap soal cerita berbasis masalah pada materi KPK.

\section{B. METODE PENELITIAN}

\section{Rancangan Penelitian}

Metode yang digunakan dalam penelitian ini adalah penelitian kualitatif. Data yang dihasilkan adalah data deskriptif yang berupa kata-kata tertulis. Strategi penelitian yang digunakan adalah metode deskriptif kualitatif. Penelitian deskriptif adalah penelitian yang memberikan gambaran dari suatu gejala yang ada dan menjawab pertanyaanpertanyaan yang ada yang berhubungan dengan status (keadaan) subyek penelitian pada saat tertentu. Pengambilan data menggunakan metode tes dan wawancara. Data yang diperoleh akan didiskripsikan atau diuraikan kembali kemudian akan dianalisis (Suryasubrata: 2015).

Penelitian ini dilaksanakan pada tanggal 8-9 Novermber 2018 di SDN 2 Tamansari. Subyek penelitian adalah siswa kelas IV SDN 2 Tamansari sebanyak 30 orang.

Sumber data dalam penelitian ini yaitu berupa tes soal. Tes soal merupakan tes yang dirancang untuk keperluan mendiagnosis kesulitan-kesulitan yang dilakukan siswa dalam menyelesaikan permasalahan pada materi KPK.

Instrumen penelitian yang digunakan dalam penelitian ini adalah: Tes soal dan wawancara.

Tes ini diadakan tanpa membuka buku. Data yang diharapkan berupa hasil pekerjaan siswa pada lembar jawab yang disertai dengan langkahlangkahnya. Tujuan diadakannya tes ini adalah untuk mengetahui sampai di mana kemampuan verbal dan numeriknya siswa dalam menyelesaikan soal KPK. Data hasil tes ini digunakan sebagai dasar menentukan subjek penelitian dan bahan pengamatan mengenai kesalahan siswa dalam menyelesaikan soal KPK. Hasil pengerjaan siswa yang telah ditetapkan sebagai subjek penelitian diberi 
skor dengan ketentuan jika siswa salah dalam menuliskan suatu langkah yang berkaitan dengan konsep dan prinsip diberi skor o dan jika siswa benar dalam menuliskannya diberi sesuai dengan bobot (penskoran) soal yang telah ditentukan dari rentang 1-4

Kumpulan data berupa skor dianalisis untuk mengetahui persentase tingkat kesulitan siswa verbal dan numerik. Pengerjaan siswa yang salah dianalisis kemudian dikelompokkan kedalam jenis-jenis kesalahan yang berkaitan dengan verbal dan numerik

\section{Wawancara}

Wawancara dilaksanakan berdasarkan pedoman wawancara yang telah disusun. Tujuan wawancara untuk menelusuri kesulitan siswa secara lebih mendalam terhadap kemampuan verbal dan numerik dalam menyelesaikan masalah matematika pada materi KPK yang berkaitan dengan verbal dan numerik

\section{Analisis Data}

Data yang diperoleh dalam penelitian ini berupa data hasil tes, dan hasil wawancara. Analisis data dilakukan secara deskriptif analitik, dengan kriteria:

a. Peserta didik mengalami kesulitan verbal terlihat dari peserta didik tidak mampu memahami soal sehingga salah mengunakan rumus dan Peserta didik kesulitan dalam membahasakan atau menarik kesimpulan dari hasil perhitungannya

b. Peserta didik mengalami kesulitan numerik terlihat dari peserta didik kesulitan dalam perhitungan kelipatan angka dan pohon faktor serta kesulitan dalam menentukan KPK dari hasil hitungan baik dari kelipatan maupun dengan pohon faktor.

Dalam penelitian ini digunakan teknik analisis data deskriptif kualitatif dengan reduksi data. Reduksi data adalah suatu bentuk analisis yang menajamkan, menggolongkan, mengarahkan, membuang data yang tidak perlu, dan mengorganisasi data dengan cara sedemikian rupa sehingga kesimpulan finalnya dapat ditarik dan diverifikasi.

Tahap reduksi data dalam penelitian ini meliputi:

a. Mengoreksi hasil pekerjaan siswa dengan cara penskoran, yang akan digunakan untuk menentukan subjek penelitian.

b. Melakukan wawancara dengan beberapa subjek penelitian, dan hasil wawancara tersebut disederhanakan menjadi susunan bahasa yang baik dan rapi.

\section{Cara Penyajian Hasil Analisis Data}

Penyajian data adalah sekumpulan informasi tersusun yang memberi kemungkinan penarikan kesimpulan dan pengambilan tindakan. Dalam tahap ini data yang berupa hasil pekerjaan siswa disusun menurut urutan objek penelitian.

Dari hasil penyajian data yang berupa pekerjaan siswa dan hasil wawancara dilakukan analisis, kemudian disimpulkan yang berupa data temuan sehingga mampu menjawab permasalahan dalam penelitian ini.

Analisis yang digunakan dalam penelitian ini adalah menurut aturan polya (1973:XVI) menetapkan empat langkah yang dapat dilakukan agar peserta didik lebih terarah dalam menyelesaikan masalah matematika, yaitu understanding the problem, devising plan, carrying out the plan, dan looking back yang diartikan sebagai memahami masalah, membuat perencanaan, melaksanakan rencana, dan melihat kembali hasil yang diperoleh. Berikut cara menghitung prosentase jumlah peserta didik dengan kemampuan verbal dan numerik dalam memecahkan masalah matematika pada materi KPK.

\section{Persentase $=\frac{\text { jumlah skor yang diperoleh }}{\text { jumlah skor maksimal }} \times 100 \%$}

Hasil penghitungan tersebut, akan dilakukan penetapan klasifikasi penafsiran data. Dalam penelitian ini akan digunakan pedoman penafsiran data seperti tercantum dalam tabel.

Tabel 1.

Penafsiran Data

\begin{tabular}{ll}
\hline Persentase & Kategori \\
\hline $0 \% \leq$ skor $<25 \%$ & Sangat kurang \\
$25 \% \leq$ skor $<50 \%$ & Kurang \\
$50 \% \leq$ skor $\leq 75 \%$ & Baik \\
$75 \% \leq$ skor $<100 \%$ & Sangat Baik \\
$($ Zuhriah, N. 2003) &
\end{tabular}

\section{HASIL DAN PEMBAHASAN}

\section{Hasil penelitian}

Penelitian ini dilaksanakan SDN 2 Tamansari dengan subjek siswa pada mata pelajaran matematika materi KPK. Pengambilan data dalam penelitian ini dilaksanakan dengan 3 tahap yaitu:

\section{a. Data Hasil Tes}

Tes dilaksanakan pada hari Jumat tanggal 9 November 2018 di kelas IV. Dari 34 peserta didik yang ikut hanya 30 peserta didik, sedangkan 4 peserta didik lainya tidak masuk.

Tes diberikan kepada peserta didik setelah seluruh materi KPK selesai diajarkan. Berdasarkan hasil pekerjaan peserta didik dalam mengerjakan soal-soal pada materi KPK, ditemukan beberapa Kesulitan menyangkup pada kemampuan verbal dan numerik yang dilakukan oleh peserta didik. Kesulitan-Kesulitan tersebut akan disajikan sebagai berikut

\section{Soal 1}

Lampu A menyala setiap 6 menit sekali dan lampu B menyala setiap 8 menit sekali. Jika saat ini kedua lampu menyala secara bersamaan, dalam berapa menit kedua lampu tersebut menyala secara bersamaan?

Tabel 2.

Deskripsi Kesulitan Jawaban Peserta didik 
pada Soal Nomor 1

\begin{tabular}{|c|c|c|}
\hline No & Deskripsi Kesulitan & No subjek \\
\hline 1 & $\begin{array}{l}\text { Peserta didik tidak mampu } \\
\text { memahami soal }\end{array}$ & $\begin{array}{l}3,4,9,15,21,25, \\
26,30\end{array}$ \\
\hline 2 & $\begin{array}{l}\text { Peserta didik kesulitan } \\
\text { dalam perhitungan } \\
\text { kelipatan angka }\end{array}$ & $\begin{array}{l}3,4,9,15,21 \\
25,26,30\end{array}$ \\
\hline 3 & $\begin{array}{l}\text { Peserta didik kesulitan } \\
\text { dalam menentukan KPK } \\
\text { dan pohon faktor }\end{array}$ & $\begin{array}{l}5,11,12,13,18 \\
28\end{array}$ \\
\hline 4 & $\begin{array}{l}\text { Peserta didik kesulitan } \\
\text { dalam membahasakan } \\
\text { atau menarik kesimpulan } \\
\text { dari hasil perhitungannya }\end{array}$ & $\begin{array}{l}1,2,5,6,7,8,10, \\
11,12,13,14, \\
16,17,18,19,20 \\
22,23,27,28\end{array}$ \\
\hline
\end{tabular}

Berdasarkan analisis yang telah dilakukan terhadap jawaban peserta didik tersebut pada kemampuan verbal diperoleh hasil bahwa pada soal nomor 1 persentase kemampuan siswa dalam menjawab benar terlihat kurang hanya 40\%, sedangkan pada kemampuan numerik diperoleh hasil bahwa pada soal nomor 1 ada $63 \%$ siswa yang menjawab dengan benar, hal ini berarti kemampuan siswa dalam numeriknya terlihat baik. Berikut perincian Kesulitan siswa yang dilakukan pada nomor 1 yaitu: 1. Siswa mengalami kesulitan dalam memahami soal dan lupa cara atau rumus menyelesaikan soal sehingga menulis kembali soal sebagai jawaban siswa dan menjawab dengan semaunya. 2. Siswa melakukan kesulitan dalam menentukan kelipatan bilangan, siswa mengalami kesulitan dalam membahasakan hasil perhitungannya sebagai jawaban akhir atas permasalahan matematika yang diberikan sehingga hanya menuliskan KPKnya saja. 3. Siswa mengalami kesulitan dalam membahasakan hasil perhitungannya sebagai jawaban akhir atas permasalahan matematika yang diberikan baik dengan cara kelipatan maupun pohon faktor,

\section{No Deskripsi Kesulitan}

1 Peserta didik tidak mampu memahami soal

2 Peserta didik kesulitan dalam perhitungan kelipatan angka

3 Peserta didik kesulitan dalam menentukan KPK dan pohon faktor

4 Peserta didik kesulitan dalam membahasakan atau menarik kesimpulan dari hasil perhitungannya

sehingga terlihat bahasa kesimpulannya masih dalam bentuk numerik.

\section{Soal no 2}

Aisyah berbelanja setiap 5 hari sekali, sedangkan Susi berbelanja setiap 4 hari sekali. Hari ini keduanya bertemu di pasar. Berapa hari lagi Aisyah dan Susi dapat bertemu di pasar?

Tabel 3.

Deskripsi Kesulitan Jawaban Peserta didik pada Soal Nomor 2
$3,4,9,15,21,25$

26,30

$3,4,9,15,21$,

$25,26,30$

$5,11,12,13,18$

$1,2,5,6,7,8,10$

$11,12,13,14,16$

$17,18,19,20$,

$22,23,27,28$

\begin{tabular}{cll}
\hline 1 & Peserta didik tidak mampu & $3,4,9,15,21$ \\
& memahami soal & $25,26,30$ \\
2 & Peserta didik kesulitan & $3,4,9,15,21$ \\
& dalam perhitungan & $25,26,30$ \\
& kelipatan angka & \\
3 & Peserta didik kesulitan & $5,11,12,13$, \\
& dalam menentukan KPK & 18,28 \\
4 & Peserta didik kesulitan & $1,2,5,6,7,8,10$ \\
& dalam membahasakan & $11,12,13,14,16$ \\
& atau menarik kesimpulan & $17,18,19,20$ \\
& dari hasil perhitungannya & $22,23,27,28$ \\
\hline \multirow{2}{*}{ Sumber: Jawaban siswa kelas IV SDN 2 Tamansari }
\end{tabular}

Berdasarkan analisis yang telah dilakukan terhadap jawaban peserta didik tersebut pada kemampuan verbal diperoleh hasil bahwa pada soal nomor 2 persentase kemampuan siswa dalam menjawab benar sebanyak 41\%, hal ini berarti kemampuan verbal siswa masih kurang, sedangkan pada kemampuan numerik diperoleh hasil bahwa pada soal nomor 2 ada 65\% siswa yang menjawab dengan benar, hal ini berarti kemampuan siswa dalam numeriknya terlihat baik. Berikut perincian Kesulitan siswa yang dilakukan pada nomor 2 yaitu : 1 . Siswa mengalami kesulitan dalam memahami soal dan lupa cara atau rumus menyelesaikan soal sehingga menulis kembali soal sebagai jawaban siswa dan menjawab dengan semaunya. 2. Siswa melakukan kesulitan dalam menentukan kelipatan bilangan, siswa mengalami kesulitan dalam membahasakan hasil perhitungannya sebagai jawaban akhir atas permasalahan matematika yang diberikan sehingga hanya menuliskan KPKnya saja. 3. Siswa mengalami kesulitan dalam membahasakan hasil perhitungannya sebagai jawaban akhir atas permasalahan matematika yang diberikan baik dengan cara kelipatan maupun pohon factor, sehingga terlihat bahasa kesimpulannya masih dalam bentuk numerik.

\section{Soal no 3}

Ema menabung di bank setiap 20 hari sekali, sedangkan Menik menabung di bank setiap 30 hari sekali. Hari ini mereka bersama-sama menabung di bank. Berapa hari lagi mereka akan menabung bersama-sama di bank?

Tabel 4 .

Deskripsi Kesulitan Jawaban Peserta didik pada Soal Nomor 3

Sumber: Jawaban siswa kelas IV SDN 2 Tamansari

Berdasarkan analisis yang telah dilakukan terhadap jawaban peserta didik tersebut pada kemampuan verbal diperoleh hasil bahwa pada soal nomor 3 persentase kemampuan siswa dalam menjawab benar terlihat kurang hanya 40\% siswa, sedangkan pada kemampuan numerik diperoleh hasil bahwa pada soal nomor 3 ada $63,3 \%$ siswa yang menjawab dengan benar, hal ini berarti kemampuan siswa dalam numeriknya terlihat baik. Berikut perincian Kesulitan siswa yang dilakukan pada nomor 3 yaitu : 1 . Siswa mengalami kesulitan dalam memahami soal dan 
lupa cara atau rumus menyelesaikan soal sehingga menulis kembali soal sebagai jawaban siswa dan menjawab dengan semaunya. 2. Siswa melakukan kesulitan dalam menentukan kelipatan bilangan, siswa mengalami kesulitan dalam membahasakan hasil perhitungannya sebagai jawaban akhir atas permasalahan matematika yang diberikan sehingga hanya menuliskan KPKnya saja. 3. Siswa mengalami kesulitan dalam membahasakan hasil perhitungannya sebagai jawaban akhir atas permasalahan matematika yang diberikan baik dengan cara kelipatan maupun pohon factor, sehingga terlihat bahasa kesimpulannya masih dalam bentuk numerik.

\section{Soal no 4}

Marbun mempunyai dua buah jam. Jam

pertama berdering setiap 25 menit dan

jam kedua berdering setiap 15 menit.

Dalam setiap berapa menit kedua jam

tersebut berdering secara bersamaan?

Tabel 5.

Deskripsi Kesulitan Jawaban Peserta didik pada Soal Nomor 4

\begin{tabular}{lll}
\hline No & Deskripsi Kesulitan & No subjek \\
\hline 1 & Peserta didik tidak mampu & $3,4,9,10,11,15$ \\
& Memahami soal & $21,24,25,26,30$ \\
2 & Peserta didik kesulitan dalam & $3,4,9,10,15,21,25$ \\
& Perhitungankelipatanangka & $26,27,29,30$ \\
3 & Peserta didik kesulitan dalam & $5,10,11,12,13,18$ \\
& menentukan KPK dan & $27,28,29,30$ \\
& pohon faktor & \\
4 & Peserta didik kesulitan dalam & $1,2,5,6,7,8,10,11$, \\
& membahasakan atau menarik & $12,13,14,16,17$ \\
& kesimpulandarihasil & $18,19,20,22,23$ \\
& perhitungannya & 27,28 \\
\hline
\end{tabular}

Berdasarkan analisis yang telah dilakukan terhadap jawaban peserta didik tersebut pada kemampuan verbal diperoleh hasil bahwa pada soal nomor 4 persentase kemampuan siswa dalam menjawab benar sebanyak $31,7 \%$, hal ini berarti kemampuan verbal siswa masih kurang, sedangkan pada kemampuan numerik diperoleh hasil bahwa pada soal nomor 4 ada 55\% siswa yang menjawab dengan benar, hal ini berarti kemampuan siswa dalam numeriknya terlihat baik. Berikut perincian Kesulitan siswa yang dilakukan pada nomor 4 yaitu : 1 . Siswa mengalami kesulitan dalam memahami soal dan lupa cara atau rumus menyelesaikan soal sehingga menulis kembali soal sebagai jawaban siswa dan menjawab dengan semaunya. 2. Siswa melakukan kesulitan dalam menentukan kelipatan bilangan, siswa mengalami kesulitan dalam membahasakan hasil perhitungannya sebagai jawaban akhir atas permasalahan matematika yang diberikan sehingga hanya menuliskan KPKnya saja. 3. Siswa mengalami kesulitan dalam membahasakan hasil perhitungannya sebagai jawaban akhir atas permasalahan matematika yang diberikan baik dengan cara kelipatan maupun pohon faktor, sehingga terlihat bahasa kesimpulannya masih dalam bentuk numerik.

Soal no 5

Amir ikut kursus komputer seminggu sekali.

Mahmud juga ikut kursus di tempat yang sama 5 hari sekali. Setiap berapa hari sekali mereka dapat bertemu di tempat kursus?

Tabel 5.

Deskripsi Kesulitan Jawaban Peserta didik pada Soal Nomor 5

\begin{tabular}{cll} 
No & Deskripsi Kesulitan & No subjek \\
\hline 1 & Peserta didik tidak mampu & $3,4,5,6,9,11,15$ \\
& memahami soal & $19,21,25,26,30$ \\
2 & Peserta didik kesulitan & $3,4,5,6,9,10,11$ \\
& dalam perhitungan kelipatan & $15,18,19,21$, \\
& angka & $25,26,27,30$ \\
3 & Peserta didik kesulitan dalam & $5,6,11,12,13$ \\
& menentukan KPK dan phon & $14,16,17,18$ \\
& factor & 19,2728 \\
4 & Peserta didik kesulitan dalam & $1,2,5,6,7,8,10$ \\
& membahasakan atau menarik & $11,12,13,14,16$ \\
& kesimpulan dari hasil & $17,18,19,20,22$ \\
& perhitungannya & $23,27,28$ \\
\hline
\end{tabular}

Sumber: Jawaban siswa kelas IV SDN 2 Tamansari

Berdasarkan analisis yang telah dilakukan terhadap jawaban peserta didik tersebut pada kemampuan verbal diperoleh hasil bahwa pada soal nomor 5 persentase kemampuan siswa dalam menjawab benar sebanyak 30\%, hal ini berarti kemampuan verbal siswa masih kurang, sedangkan pada kemampuan numerik diperoleh hasil bahwa pada soal nomor 5 ada $40 \%$ siswa yang menjawab dengan benar, hal ini berarti kemampuan siswa dalam numeriknya masih kurang. Berikut perincian Kesulitan siswa yang dilakukan pada nomor 5 yaitu : 1 . Siswa mengalami kesulitan dalam memahami soal dan lupa cara atau rumus menyelesaikan soal sehingga menulis kembali soal sebagai jawaban siswa dan menjawab dengan semaunya. 2. Siswa melakukan kesulitan dalam menentukan kelipatan bilangan, siswa mengalami kesulitan dalam membahasakan hasil perhitungannya sebagai jawaban akhir atas permasalahan matematika yang diberikan sehingga hanya menuliskan KPKnya saja. 3. Siswa mengalami kesulitan dalam membahasakan hasil perhitungannya sebagai jawaban akhir atas permasalahan matematika yang diberikan baik dengan cara kelipatan maupun pohon faktor, sehingga terlihat bahasa kesimpulannya masih dalam bentuk numerik.

Setelah mendeskripsikan Kesulitan-Kesulitan siswa dalam mengerjakan soal di atas maka dapat di jumlahkan setiap butir soal untuk kemampuan verbal dan numerik dengan menggunakan pendekatan pemecahan masalah versi polya.

Tabel 6.

Hasil jumlah skor kemampuan verbal tiap butir soal

\begin{tabular}{cc}
\hline No Soal & Jumlah skor \\
\hline 1 & 24 \\
2 & 25 \\
3 & 24 \\
4 & 19 \\
5 & 18 \\
\hline
\end{tabular}

Tabel 7.

Hasil Jumlah skor kemampuan numerik tiap butir soal No Soal Jumlah skor 


\begin{tabular}{ll}
\hline 1 & 38 \\
2 & 39 \\
3 & 38 \\
4 & 33 \\
5 & 24 \\
\hline
\end{tabular}

\section{b. Data Hasil Wawancara}

Untuk menelusuri kesulitan peserta didik dalam menyelesaikan soal-soal matematika kemampuan verbal dan numerik pada materi KPK, maka dilakukan wawancara yang dilaksanakan pada hari sabtu 10 November 2018.

Tabel 8.

Rekap wawancara 4 peserta didik

\begin{tabular}{|c|c|c|}
\hline No & Nama & Alasan \\
\hline 1 & $\begin{array}{l}\text { Rangga } \\
\text { Aditiya }\end{array}$ & $\begin{array}{l}\text { karena dapat di lihat dari hasil } \\
\text { jawaban siswa yang menulis kembali } \\
\text { soal sebagai jawaban pada soal no } 1 \text {, } \\
2,3,4,5 \\
\text { karena di lihat dari jawaban no } 1,2 \text {, }\end{array}$ \\
\hline 2 & $\begin{array}{l}\text { Fakhrul } \\
\text { Maulana } \\
\text { Majdi }\end{array}$ & $\begin{array}{l}\text { 3, } 4 \text { yang tidak menentukan KPK dan } \\
\text { tidak menarik kesimpulan. salah } \\
\text { dalam mengartikan soal no } 5\end{array}$ \\
\hline 3 & Zila Ramdani & $\begin{array}{l}\text { karena di lihat dari jawaban siswa } \\
\text { yang salah menentukan KPK dari } \\
\text { pohon faktor serta penarikan } \\
\text { kesimpulan yang salah dari soal no } 1 \text {, } \\
2,3,4.5\end{array}$ \\
\hline 4 & Zianul Ulum & $\begin{array}{l}\text { karena di lihat dari jawaban siswa } \\
\text { dalam menarik kesimpulan dengan } \\
\text { bahasa salah pada soal no } 1,2,3,4,5\end{array}$ \\
\hline
\end{tabular}

Table 9.

Data Hasil Wawancara Kemampuan Verbal dan Numerik kepada 4 Peserta Didik

\begin{tabular}{|c|c|c|}
\hline Nama subjek & Nomor soal & Hasil wawancara \\
\hline Rangga Firdaus & $1,2,3,4,5$ & $\begin{array}{l}\text { Peserta didik tidak } \\
\text { memahami soal }\end{array}$ \\
\hline Fakhrul Maulana & $1,2,3,4,5$ & $\begin{array}{l}\text { Peserta didik } \\
\text { kesulitan menentukan } \\
\text { KPK pada soal no } 1,2 \text {, } \\
3,4 \text { dari hasil } \\
\text { perhitungannya Tidak } \\
\text { memahami soal dalam } \\
\text { bentuk verbal yang } \\
\text { terdapat pada nomor } 5\end{array}$ \\
\hline Zila Ramadani & $1,2,3,4,5$ & $\begin{array}{l}\text { Peserta didik tidak bisa } \\
\text { menentukan KPK dari } \\
\text { hasil perhitungan } \\
\text { pohon faktor pada soal } \\
\text { no } 1,2,3,4 \text {,dan } 5 \\
\text { Peserta didik kesulitan } \\
\text { dalam membahasakan } \\
\text { atau menarik } \\
\text { kesimpulan dari hasil } \\
\text { perhitungannya }\end{array}$ \\
\hline Zianul Ulum & $1,2,3,4,5$ & $\begin{array}{l}\text { Peserta didik kesulitan } \\
\text { dalam membahasakan } \\
\text { atau menarik } \\
\text { kesimpulan dari hasil } \\
\text { perhitungannya }\end{array}$ \\
\hline
\end{tabular}

Sumber: siswa kelas IV SDN 2 Tamansari
Dari hasil semua jawaban soal peserta didik pada kemampuan verbal dan numerik, peserta didik mengalami kesulitan pada kemampuan verbal dan numerik di lihat dari kriteria kesulitan sebagai berikut.

Tabel 10.

Hasil Persentase Kemampuan Verbal

\begin{tabular}{ccc}
\hline No soal & Persen & Kategori \\
\hline 1 & $40 \%$ & Kurang \\
2 & $41,7 \%$ & Kurang \\
3 & $40 \%$ & Kurang \\
4 & $31,7 \%$ & Kurang \\
5 & $30 \%$ & Kurang \\
\hline
\end{tabular}

Tabel 11.

Hasil Persentase Kemampuan Numerik

\begin{tabular}{ccc}
\hline No Soal & Persen & Kategori \\
\hline 1 & $63,3 \%$ & Baik \\
2 & $65 \%$ & Baik \\
3 & $63,3 \%$ & Baik \\
4 & $55 \%$ & Baik \\
5 & $40 \%$ & Kurang \\
\hline
\end{tabular}

Terlihat pada tabel 10 dan 11 pada umumnya peserta didik yang menjawab soal dengan benar terhadap setiap butir soal sangat relative rendah. Dari hasil peserta didik dapat diketahui bahwa peserta didik yang mengalami kesulitan pada soalsoal matematika kemampuan verbal dan numerik materi KPK hampir sama pada setiap butir soalnya.

Hasil analisis data berdasarkan tes kemampuan verbal dan numerik yang dilakukan dan wawancara dengan peserta didik menunjukkan, bahwa peserta didik mengalami kesulitan dalam menyelesaikan persoalan materi KPK yang diberikan. Kesulitan peserta didik pada umumnya berupa kesulitan dalam memahami soal dan menarik kesimpulan dari jawaban yang telah diperoleh. Kesulitan peserta didik tentang hal tersebut mengakibatkan peserta didik menggunakan prosedur penyelesaian soal yang tidak benar dan tidak menemukan kesimpulan jawaban dari apa yang telah mereka hitung.

Tingkat kesulitan yang dialami peserta didik sebagai berikut:

a. Peserta didik kurang mampu memahami permasalahan atau soal yang diberikan, sehingga siswa menjawab dengan menuliskan kembali soal yang dianggap sebagai jawaban, dan siswa menjawab dengan semaunya tanpa menggunakan cara apapun

b. Siswa mengalami kesulitan dalam perhitungan sehingga siswa mengerjakan sebagian langkahlangkah penyelesaian artinya tidak menyelesaikan sampai tuntas

c. Siswa sulit dalam membahasakan hasil perhitungannya sebagai jawaban akhir atas permasalahan matematika yang diberikan.

d. Peserta didik tidak memahami rumus dan salah berhitung, hal ini terlihat pada saat siswa melakukan Kesulitan dalam menentukan 
kelipatan dan salah dalam menentukan KPK dengan pohon faktor.

\section{KESIMPULAN DAN SARAN}

\section{Kesimpulan}

Berdasarkan hasil tes dan analisis jawaban siswa Berdasarkan hasil tes dan analisis jawaban siswa diperoleh factor-faktor yang mempengaruhi kesulitan belajar siswa. Adapun yang mempengaruhi kesulitan peserta didik dalam kemampuan verbal adalah peserta didik kurang mampu memahami permasalahan atau soal yang diberikan, sehingga siswa menjawab dengan menuliskan kembali soal yang dianggap sebagai jawaban dan menjawab dengan semaunya tanpa menggunakan cara apapun dan siswa mengerjakan sebagian langkah-langkah penyelesaian artinya tidak menyelesaikan sampai tuntas, selain itu siswa sulit dalam membahasakan hasil perhitungannya sebagai jawaban akhir atas permasalahan matematika yang diberikan. sedangkan kemampuan numerik adalah peserta didik tidak memahami rumus yaitu salah dalam menentukan kelipatan dan salah dalam menentukan KPK dengan menggunakan pohon factor, selain itu siswa menjawab dengan semaunya tanpa menggunakan cara apapun dikarenakan lupa rumus. Faktor lain yang mempenagruhi kesulitan siswa dalam menyelesaikan masalah matematika diperoleh dari hasil wawancara adalah kurangnya latihan dalam menyelesaikan masalah matematika dan metode mengajar guru yang kurang mengaitkan pembelajaran dengan permasalahan dalam kehidupan sehari-hari

\section{Saran}

a. Untuk siswa agar terus belajar latihan meyelesikan soal untuk meningkatkan kemampuan pemahamannya dalam memecahkan masalah matematika baik dari segi kemampuan numerik maupun kemampuan verbal

b. Bagi guru

(1) Guru dalam membentuk pola pengajaran matematika hendaknya lebih mengajak peserta didik untuk memahami dan mengerti serta menguasai materi-materi yang ada secara baik dan benar, sehingga peserta didik tidak mengalami kesulitan dalam menyelesaikan permasalahan matematika pada umumnya dan materi KPK pada khususnya

(2) Guru diharapkan menggunakan strategi atau metode mengajar yang lebih kreatif guna meningkatkan kemampuan verbal dan numerik. Siswa dalam menyelesaikan masalah matematika

(3) Guru diharapkan selalu memberikan motivasi belajar kepada peserta didik agar peserta didik mempunyai perhatian dan minat dalam belajar matematika

(4) Guru secara rutin memeberikan latihan-latihan soal pemecahan masalah matematika

\section{DAFTAR RUJUKAN}

[1] Permendiknas No.22 tahun 2006. SISDIKNAS.Bandung:Citra Umbara

[2] Polya, G. 1973, How To Solve It. New Jersey: Princeton University Press.

[3] Sukardi, 2015. Analisis Tes Psikologis. Bandung : Rineka Cipta

[4] Suryasubrata, S. 2015. Psikologi pendidikan. Jakarta: Rajawali Pers. 